Open Access

\title{
The effect of EU 2006 sugar regime reform on vertical price transmission
}

\author{
Maurizio Aragrande ${ }^{1 *}$ (D) Mauro Bruni ${ }^{2}$, Alberico Loi $^{3}$ and Roberto Esposti ${ }^{4}$
}

\author{
* Correspondence: \\ maurizio.aragrande@unibo.it \\ ${ }^{1}$ Department of Agricultural and \\ Food Sciences, University of \\ Bologna, via G. Fanin 50, 40127 \\ Bologna, Italy \\ Full list of author information is \\ available at the end of the article
}

\begin{abstract}
CAP regulation of sugar sector has frequently been questioned because of its potential effect on competition. In 2006 the CAP reform of the sugar sector established a relevant break in policy trend with potential albeit untargeted effects on price transmission. In 2012 DG AGRI commissioned a study to assess the effects of the 2006 reform of the EU sugar regime on the price transmission within the sugar sector. This paper highlights the effects of the new CAP sugar regime on sugar retail price and on the degree of competition and concentration in the sugar industry. Vertical price transmission is tested through econometric models. The relationship between concentration and competition is analysed putting in relation the concentration index and a modified version of the Lerner index. Results of empirical investigation show that vertical price transmission asymmetries still exist after the reform, which in turn contributed to increase sugar sector concentration, partly confirming the validity of the Structure-Conduct-Performance assumptions. The sugar market is far from efficient and the reform only created more favourable conditions for its improvement.

Keywords: Sugar reform, Vertical price transmission, EU
\end{abstract}

\section{Background}

Price transmission measures how the price variation of a good in a market is transmitted to derived goods in other markets. The transmission varies vertically along the supply chain, horizontally among spatially linked markets, or among the markets of substitute products. The relevant point within the sugar industry is how sugar price variations are transmitted downstream to the price of sugar for consumption or goods containing sugar. Sugar beet processors play a special role in the implementation of the Common Market Organisation (CMO) which directly targets industrial products (sugar and its derivatives) to sustain sugar beet producers. The functioning of sugar CMO has been frequently questioned because of its potential influence on competition and sugar companies' strategies. It might lead to the creation or strengthening of market power of processing companies to the detriment of the downstream stages of the supply chain and consumers, thus reducing consumer's surplus (OECD 2007). Upstream the supply chain, the exertion of market power might theoretically hit beet producers (e.g. in case industrial oligopsony with market power occurs), thus reducing the effectiveness of Common Agricultural Policy (CAP) measures on the setting of sugar beet price. Consumer welfare and policy effectiveness are the main social and economic concerns related to the exertion of market power within the sugar supply chain.

(c) The Author(s). 2017 Open Access This article is distributed under the terms of the Creative Commons Attribution 4.0 International License (http://creativecommons.org/licenses/by/4.0/), which permits unrestricted use, distribution, and reproduction in any medium, provided you give appropriate credit to the original author(s) and the source, provide a link to the Creative Commons license, and indicate if changes were made. 
The empirical assessment of market power is a complex issue which has raised a multiplicity of investigation methods until recently. Digal and Ahmadi-Esfahani (Digal and Ahmadi-Esfahani, 2002) trace back that complexity to the Structure-ConductPerformance (SCP) paradigm, the New Empirical Industrial Organisation (NEIO) approach and time series approach. The Bain's SCP paradigm (Bain, 1951) establishes a straight relationship between industry concentration and firms' strategies, and consequently between strategies and market performance. Performance refers to market efficiency in resource allocation, which would increase in perfect markets to the detriment of firms' profit (and vice-versa in imperfect markets).

SCP paradigm has been criticised according to a variety of reasons. Among these, the assumption of industry structure as an exogeneous variable is relevant here, simply because feedback of performance and/or conduct toward the structure may exist. If the latter occurs, the typical SCP causal link would be reversed as the structure would be a result of the conduct. This entails a conceptual problem, which, in a typical SCP model, structure and performance would be logically endogenous. For example, if one accepts the Lerner index and the Herfindal index as measures of firm performance and market structure respectively, they both would be endogenous and simultaneously determined, thus "making it impossible to infer the direction of causality between market structure and performance" (Sheldon and Sperling, 2003, p. 91). Higher profits may depend from other factors than market power, namely firm efficiency to name just one (Digal and Ahmadi-Esfahani, 2002, p. 562).

Further concerns are about the direct observability of price-cost margins and whether high profits (i.e. firm performance) should be associated with good or bad market performance (Bresnahan 1989, p. 1013), thus questioning the effect of concentration on consumer welfare. NEIO studies put forward some conceptual and operational differences with respect to SCP. Starting from the assumption that firm conduct has to be observed in its economic and structural environment, NEIO studies focus on the conduct of firms within a particular industry. In this context, firm conduct is not assumed a priori, but empirically tested (e.g. via conjectural models about firm behaviour under different competitive assumptions). The same method goes for price-cost margins which are not measured but instead they are derived from microeconomic models of supply and demand of the industry (Bresnahan, 1989; Sheldon and Sperling, 2003).

The time series approach allows for the analysis of price movements between markets which are vertically linked along the supply chain (vertical price transmission, VPT) or spatially related (horizontal price transmission), or between the markets of related products. Data required to run time series models, that are market prices occurring in the markets, are relatively easy to find and make these models easier than typical SCP and NEIO ones (Digal and Ahmadi-Esfahani, 2002, p. 563) and this data availability probably explains their diffusion.

VPT studies are based on the assumption that firms can avoid to transmit price variations (e.g. decreases) from upstream to downstream levels or vice versa, and increase their profits consequently (firm performance). The analysis of price movements results in elasticity coefficients which assess price symmetry or asymmetry in speed and/or magnitude, nature and direction (Meyer and Von Cramon-Taubadel, 2004). Peltzman's work (Peltzman, 2000) gave VPT studies a strong impulse, as the same methodology was applied to a wide range of product categories (agro-food products in particular) 
revealing that asymmetries in price transmission are often the rule rather than the exception in real markets. Once VPT is assessed, the issue goes back to whether market power can be simply inferred from the existence of asymmetries via industry concentration (as the SCP paradigm suggests) or not. Empirical evidence is mixed and it does not allow for simple generalisations about the causes of price asymmetries (Meyer and Von Cramon-Taubadel, 2004; Vavra and Goodwin 2005, Cavicchioli, 2010).

VPT studies provide a variety of explanations to asymmetries that go beyond market power, and this clearly emerges even from the analysis of a restricted sample of literature. Within the VPT framework, the argument of firm/industry costs holds a central place among the causes of asymmetries. More specifically, different hypotheses about return to scale (e.g. increasing) may give reason of weak price transmission as firms, for example, can offset the increase of input price by way of increased efficiency (Bettendorf and Verboven, 2000; McCorriston et al., 2001; Wang et al., 2006).

Transaction cost may affect price transmission in different ways. On the supply side, menu costs may prevent retailers from changing selling price despite variations of input prices or inflation (Ball and Mankiw, 1994); the organisation of stock management procedure (i.e. first-in-first-out and last-in-first-out of the stock) may determine time lags in price transmission (Reagan and Weitzman, 1982; Wohlgenant, 1985). Kimmel (Kimmel, 2009) develops practical reasoning about the process that lead firms to react to decrease/ increase of input price, mixing considerations about cost structure, transaction cost which are implicit in the decision-making process regarding output level (e.g. via contracts, advertising), expectations, and the inherent time lag of decision making itself. On the demand side, transaction cost may also be effective if consumer search cost in oligopoly appears (Chavas and Mehta, 2001, p. 1; Sheldon and Sperling, 2003, p. 103).

Modification of the macroeconomic framework started an interesting stream of studies which puts price transmission in relation with inflation and commodities price hikes (Bukeviciute et al., 2009), and with taxation (Bonnet and Réquillart, 2013). Supply and demand functions' shape may also influence price transmission elasticity (Kinnucan and Forker, 1987; Azzam, 1999; Xia, 2009). A peculiar case in this chapter is the effect of food crises on price transmission. In such a context, falling demand or falling supply determines certain situations, which combines with imperfect information (e.g. food scare) and the pre-existing structure of the sectors involved (Aragrande and Canali, 2017). Edging toward the focus of this paper, changes of the institutional framework (e.g. CAP measures such as decoupling, quota, price floor; retail policy) have also been studied because of their effect on price transmission (Ferrucci et al., 2010; Bolotova and Novakocic, 2012; Cacchiarelli et al., 2016).

Finally, we would like to make two last remarks about methodology. In the effort of shedding light on the reasons behind price asymmetries, Bakucs, Falkowski, and Fertő developed a meta-analysis of price transmission studies within the agro-food sector (Bakucs et al., 2014). This is an innovative perspective in this field and it revealed the relation of some "sets of factors" (e.g. farm sector structure, retail regulation, public support, etc.) with symmetric or asymmetric farm-retail price transmission in relation to country and/or product specifications.

Last but not least, part of this debate is around the methods to test price transmission, which is inexorably evolving since decades. Aiming at classifying the types of asymmetries and the methods used to assess them, Frey and Manera 
conclude that each model fits better to detect some types of asymmetries and, in turn, each type of asymmetry is better caught by specific models (Frey and Manera, 2007).

In 2012 the Commission's Directorate-General for Agriculture and Rural Development (DG AGRI) commissioned a study ${ }^{1}$ to assess, among others, the influence of the 2006 reform of the EU sugar regime on:

a) The price transmission within the sugar sector

b) The industrial concentration and competition in the sector

The 2006 reform of the sugar sector is the most recent step of a reforming process, which dates back to the World Trade Organization (WTO) establishment. Differently from previous attempts, this reform established a relevant break in the policy trend, and provided the opportunity to study the effects of the reform on price transmission (an unintended but not less relevant outcome of the reform). In 2011 the European Commission-Directorate General for Agriculture and Rural Development (DG AGRI) launched a study to assess the effects of 2006 sugar reform on price transmission in the European Union (EU) sugar industry. The study took into account the sugar sector situation up to the end of 2011. Starting form sugar industry, VPT was tested toward upstream and downstream sectors (respectively agriculture, and processing industry and retail). Furthermore, the impact of the reform on competition and concentration was tested. The study covered all of the Member States (MS) of the EU, which were grouped in sub-set of relevant countries (e.g. EU-15, NMS-12). Limited availability of data sometimes forced scholars to focus on more limited groups.

This paper reports about the result of the study. Its relevance should be ascertained in consideration of the elements listed below:

i. The absence of studies on price transmission in the sugar sector since the 2006 reform, as far as we know

ii. The geographical scope, which covers all of the EU Member States (with the sole limitation of availability, completeness and reliability of the existing data series), differently from previous research which was primarily based on simulation (OECD 2007) or focusing on individual Member States (Nolte et al., 2012; Hamulczuk and Szajner, 2015; Varga, 2007; Dejgård and Møller, 2007)

iii. The analysis of competition based on original price-cost margins data of sugar industry (an Adjusted Lerner Index modified to preserve industrial sensitive data was calculated)

iv. The analysis of concentration of the EU sugar industry (first and second degree) in a wide range of $\mathrm{EU}$ countries

In the following pages, the "Methods" section explains the methodology adopted to develop the study; the "Results" section introduces the results of the theoretical and empirical analysis; the "Discussion" section discusses some outcomes and limitations of the study; and the "Conclusions" section draws general conclusions. 


\section{Methods}

The study adopted qualitative and quantitative methodology to comply with the objectives of the research. The 2006 reform of the sugar sector brought some relevant modifications of the former regime, which concerned both the domestic market regulation and trade. As a reference point for this study, Table 1 below outlines the relevant modifications brought about by the 2006 reform (Council Regulation (EC) 318/2006; 320/2006; 1234/ 2007; 1261/2007) in comparison with the previous situation (Council Regulation (EC) 1260/2001 and successive modifications).

\section{The qualitative approach}

The qualitative approach included in depth analysis of the EU sugar regime measures. This analysis aimed to outline the relevant changes concerning the regulation of the domestic market and the trade with Third Countries, including price and quota system, import limitations and derogations, export refund system and restructuring aid.

A revision of price transmission theories was developed in order to identify the policy measures potentially affecting VPT. The guaranteed price system, the management of sugar production and the management of import and export flows were the most relevant measures, and a theoretical analysis of their expected effects was developed. Each measure was analysed separately under a ceteris paribus assumption, focusing the sugar industry.

The analysis also concerned the potential effects of the same measures on concentration and competition within the sector, and how they might influence price transmission directly and indirectly. The SCP approach and Porter's approach to competition (Porter, 1985) guided this part of the research. A global view of the theoretical analysis concerning the reform's effects on VPT, concentration and competition was finally provided. This part of the study allowed for the formulation of hypothesis to be tested by the quantitative approach.

\section{The quantitative approach}

Listorti and Esposti (Listorti and Esposti, 2012) recently reviewed the wide empirical literature on agricultural price transmission also in the presence of non-linearities. These latter may be the consequence of temporary price peaks but also of a regime change induced by a new policy. The current methodological toolkit offers two possible solutions on how to include policy regime changes within price transmission model. A first intuitive way is to assume that a regime change intervenes at a perfectly known point in time and permanently changes the cointegration relationship among prices. So, it

Table 1 The 2006 sugar reform. Overview of the relevant modifications

\begin{tabular}{ll}
\hline Type of measures & Trend in comparison with pre-reform status \\
\hline 1. Guaranteed price system & Reduction of price support \\
2. Production quotas & Promotion of reduction of both in-quota and out-of-quota production \\
3. Market withdrawals & Termination of public intervention \\
4. Restructuring & Radical change in the approach (from "helping laggards" to "selecting the best") \\
5. Regulation of import & Improved market access for sugar produced in LDCs and in non-LDC ACP countries \\
6. Export refunds & Greatly reduced room for recourse to subsidised exports \\
\hline
\end{tabular}

Source: Adapted form (Areté srl Research and Consulting in Economics, 2012) 
behaves like an exogenous (i.e. independent on price changes themselves) structural break of the long-term price relationship while not affecting their short-term interdependence. A second and more sophisticated approach collects a set of alternative variants under the common label of regime-dependent or state-dependent Vector Error Correction Models (VECM). Among the possible specifications of this latter approach, recent empirical literature has mostly focused on the so-called threshold cointegration where the change in the price transmission relationship occurs when some price exceeds a given value, so the regime change is, in this respect, endogenous (Goodwin and Harper, 2000; Abdulai, 2002; Balcombe et al., 2007; Rezitis and Stavropoulos, 2011). It must be emphasised, however, that the common feature of the threshold cointegration approach is that it concentrates the non-linearity of price transmission (i.e. the regime change) in the adjustment and short-run parameters, leaving the long-run equilibrium unchanged (not regime dependent). In practice, threshold cointegration and structural break modelling are, in fact, complementary rather than alternative solutions and a combination of the two should be actually adopted to admit policy changes to affect both the short-run and the long-run price transmissions.

Eventually, such empirical solutions are highly data demanding for the large number of parameters to be identified, thus requiring quite long high-frequency time series. These conditions are not met with the data set under analysis here. Moreover, threshold cointegration seems more suited to analyse non-linear price transmission during period of market instability and whenever the timing and the causes of this change in regime are hardly identifiable rather than when non-linearities are generated by a wellidentified exogenous external factor, like a change in policy regime.

The quantitative approach, here adopted to test the effect of the CAP sugar reform on VPT, concentration and competition, enters the policy regime change as a structural break. The policy-related breaks, adopted to structure statistical investigation, are:

- November 2005: achievement of a political compromise on the content of the reform

- March 2006: publication of the implementing regulation on the Official Journal

- July 2006: entry into force of the regulation, start of the first EU sugar marketing year (MY) under the reformed ${ }^{2}$ regime

The preliminary visual inspection of data series and qualitative analysis also followed the relevant events related to changes in the CAP and firms' strategies (e.g. mergers, acquisitions). Table 2 below displays a list of the abovementioned events in relation to the main investigation area of the study (within brackets in table headlines).

\section{Testing VPT}

Vector Autoregression Model (VAR) and Vector Error Correction Model (VECM) were adopted for the assessment of time series (Sims, 1980; Engle and Granger, 1987). In the VAR model variables were used symmetrically, thus we included an equation for each variable in order to explain its evolution based on its own lags and the lags of the other variables in the model. VECM is considered an extension of VAR model allowing the distinction between short-run and long-run dynamics.

In this study, the short-term time horizon is defined by the maximum number of monthly lags (nine) which we considered for the purposes of the assessment following economic considerations linked to duration of supply contracts in the sugar sector. 


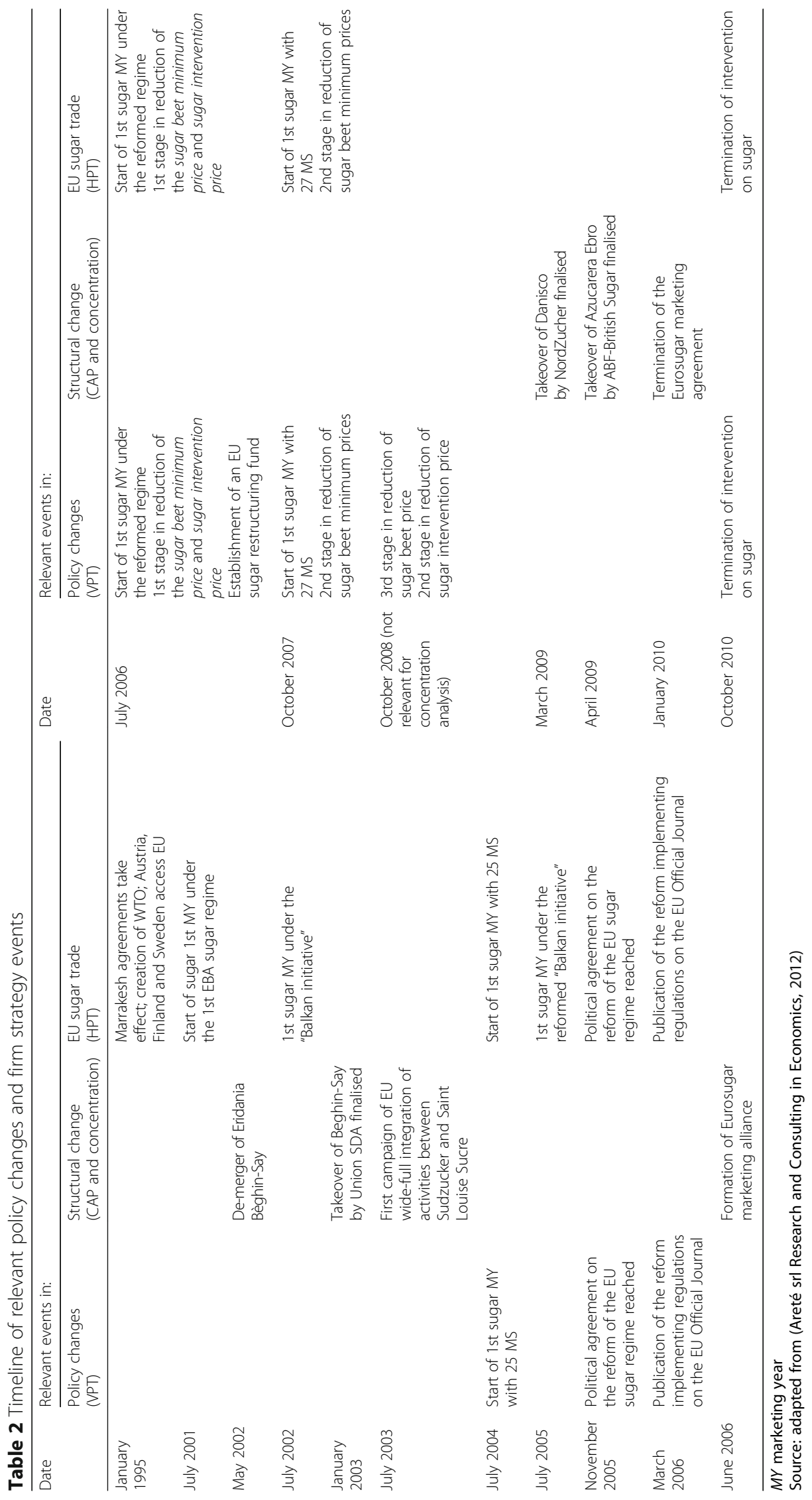


The long-term time horizon was defined by a period which extends for the entire length of each subsample, varying from 6 to 11 years according to the key issues considered. Possible presence of both short-term and long-term PT was systematically investigated through econometric tests in the framework of the key questions.

The abovementioned models were used to analyse connections between series of prices referring to different levels of the supply chain, in order to understand the way price transmission works within the sector. Moreover, those models allowed to detect possible delayed reactions among variables, which were deemed to be particularly relevant in the analysis of price transmission mechanisms, as price adjustments often were distant in time from each other.

Speed, intensity and the existence of asymmetry were also investigated. The sugar industry was the pivotal reference to test price transmission. VPT was tested upstream toward agricultural sector for sugar beet price, and downstream toward the retailing sector for retail price. Tests were performed in the relevant sugar-producing countries and different EU Member State aggregations (EU-15, NMS-12, EU-25 and EU-27), depending on the specific issue. The potential effects of the reform were analysed taking into account the absolute level of price, its variation and the relation between prices occurring within two different markets over a certain time span. In particular, VPT was tested by taking into account the relation between ex-work and retail prices and vice versa in the pre- and post-reform periods. ${ }^{3}$

\section{Testing concentration and competition}

Due to confidentiality issues concerning sugar production cost data, an ad hoc procedure was adopted to treat the Lerner Index-defined as [(sugar price - sugar production cost)/ (sugar price)]-in the assessment, thus shaping a modified version of the Lerner index. Time series of the Lerner Index were calculated by DG Agriculture on the basis of sugar ex-work prices and of LMC International sugar production cost data. The values of the Lerner Index were then multiplied by an unknown constant, different for each Member State. The resulting time series are referred to in this study as "Adjusted Lerner Index" (ALI). The abovementioned procedure allowed comparisons of time series of the ALI between Member States only in terms of dynamics, not of absolute level of the ALI itself. We assessed the effects of the reform on competition by observing the evolution of the index against the succession of policy-related and industry-related significant events (see Table 2 above), which we considered in the study of the evolution of other variables concerning competition as well (number of producers, number of beet sugar factories in operation, average production capacity of such factories).

The relationship between the evolution of the Herfindahl-Hirschman Index (HHI) and the ALI in the 2000-2011 period was investigated through statistical methods, in order to detect the possible presence of correlation, and hence to assess consistency with or deviation from the classic SCP paradigm. The evolution of all the relevant prices was then studied against the evolution of the ALI through econometric methods, which allowed to empirically assess the impact of the evolution of concentration and competition on price transmission. The 2006 reform of the EU sugar regime was considered as the policy-related break for the assessment. ${ }^{4}$

The time series which underwent econometric testing were updated to the end of 2011. As a consequence, we carried out an empirical assessment, which did not cover the potential influence of ex-work price increases occurred in the first months of 2012. 
Datasets were sometimes incomplete in terms of time and/or geographical coverage, ${ }^{5}$ as Table 3 below synthetically reports.

The relationship between concentration and performance is critical to the SCP paradigm for the reasons we presented in the "Background" referring to Sheldon and Sperling (Sheldon and Sperling, 2003). Within the limits of the DG AGRI mandate, in this study we exploited the availability of original data on concentration and performance to shed light on that relationship. Being aware of the limitation of the exercise, we did not aim to be conclusive in that respect. Finally, in spite of the above limitations, we claim that a peculiarity and a strength of the assessment methodology is precisely this use of production cost data for computing a direct measure of competition (ALI), instead of an indirect assessment through conduct parameters.

\section{Results}

As mentioned above in "Methods", the theoretical analysis of the potential effects of the reform of VPT and concentration and competition (qualitative analysis) allowed for the formulation of hypothesis to be tested with the quantitative analysis. Following this approach, in the next paragraph, we will first recall the results of the theoretical assessment and then we will show the results of the quantitative tests. In both cases, VPT and competition will be treated separately.

\section{Theoretical assessment of the potential effects of CAP reform}

\section{a) Vertical price transmission and concentration.}

VPT is affected by the reduction of the minimum price for quota sugar beets: downward variations of sugar beet prices still face an absolute limit after the reform; however, the variation floor has been lowered, showing a clear direct influence of the reform on upstream VPT. No element of the reformed sugar regime can exert per se a direct influence on downstream VPT, but some of them might influence price transmission by means of their effect on concentration and competition.

Progressive price reduction allows in the first place for a greater range of price variation. This does not determine VPT but establishes a preliminary condition for greater price movements. Assuming that internal competition in the sugar sector is

Table 3 Data set availability and geographical coverage of econometric test

\begin{tabular}{|c|c|c|}
\hline $\begin{array}{l}\text { Performed econometric } \\
\text { test }\end{array}$ & EU-15 MS & NMS-12 MS \\
\hline $\begin{array}{l}\text { Vertical price } \\
\text { transmission }\end{array}$ & $\begin{array}{l}\text { Austria, Belgium, France, Finland, Germany, } \\
\text { Greece, Italy, Netherlands, Portugal, Spain, } \\
\text { Sweden, United Kingdom }\end{array}$ & $\begin{array}{l}\text { Bulgaria, Czech Republic, } \\
\text { Hungary, Lithuania, Poland, } \\
\text { Romania, Slovakia }\end{array}$ \\
\hline $\begin{array}{l}\text { Policy reform vs. } \\
\text { concentration and } \\
\text { competition }\end{array}$ & $\begin{array}{l}\text { Austria, Belgium, France, Finland, Germany, } \\
\text { Greece, Italy, Netherlands, Spain, United Kingdom }\end{array}$ & $\begin{array}{l}\text { Czech Republic, Hungary, Poland, } \\
\text { Romania, Slovakia }\end{array}$ \\
\hline $\begin{array}{l}\text { ALI vs. ex-work sugar } \\
\text { price }^{(*)}\end{array}$ & $\begin{array}{l}\text { France, Germany, Greece, Spain, United } \\
\text { Kingdom }\end{array}$ & $\begin{array}{l}\text { Czech Republic, Hungary, } \\
\text { Poland, Romania }\end{array}$ \\
\hline $\begin{array}{l}\text { ALI vs. retail prices of } \\
\text { sugar containing }^{\left({ }^{*}\right)}\end{array}$ & $\begin{array}{l}\text { France, Germany, Greece, Spain, United } \\
\text { Kingdom }\end{array}$ & $\begin{array}{l}\text { Czech Republic, Poland, } \\
\text { Romania }\end{array}$ \\
\hline
\end{tabular}

Legend: Italic character: sub-optimal dataset; bold character: comparison pre/post reform was possible; $\left(^{*}\right)$ Monthly observations, January 2000 to October 2011. Source: adapted from Areté srl Research and Consulting in Economics, 2012 
mainly based on scale economies, reduced price support combined with reduced production quotas should theoretically promote cost-based competition among producers, leading toward an increased concentration. In this regard, it is worth remembering that price floor is not limited by the intervention price, and a reference price (which is not a guaranteed price) substituted it.

The reduction of import barriers makes it possible for Third Countries to sell increasing quantities of sugar in the EU market at reduced price and under preferential agreements (countries under tariff exemption). This situation is likely to occur because the revised quota system reduces EU domestic supply potential and, when the EU market price is higher than world price, those countries would find profitable to export to EU. Such import would increase pressure toward the reduction of domestic cost, depending on the importance of imported volume, of course. Once more, the downward revision of the quota system might push sugar firms to maintain or develop their production potential adopting the clause of re-allocation of national production or by other means (quota trade, mergers and acquisitions are typical means used in the sugar sector). It can be assumed that all of these factors may lead sugar companies to implement cost rationalisation and scales economies, finally concurring to increase industrial concentration. In turn, increased concentration might translate in lower competition and increased market power, potentially affecting VPT (Fig. 1). However, it is essential to consider that price dynamics within the EU market respond to the evolution of market fundamentals as well (production, imports, exports, consumption and stocks). The latter can also be influenced by policy decisions taken by the European Commission (e.g. the granting of additional preferential import quotas and the re-classification of "out of quota production" as "in quota production" which can be marketed domestically).

b) Competition

Effects on competition were analysed through Porter's five forces competition scheme (Fig. 2) by filtering the measures which the sugar reform brought in.

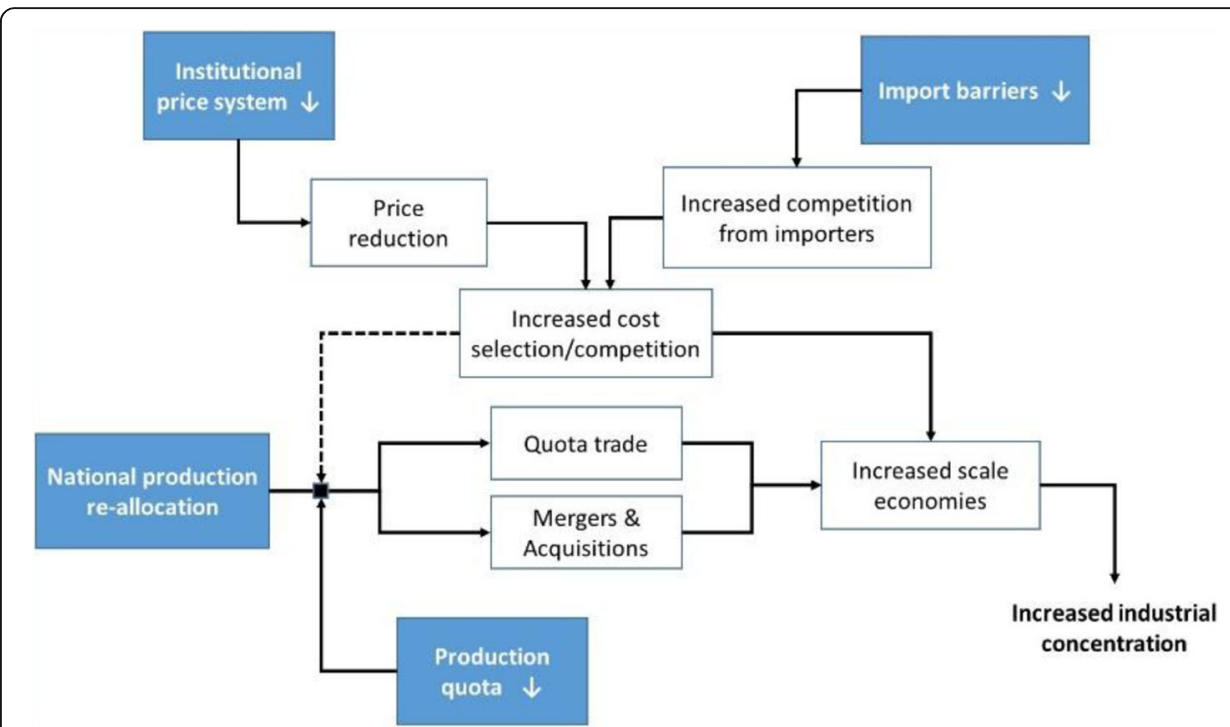

Fig. 1 Potential effect of sugar CMO Reform on concentration. Adapted from Areté srl Research and Consulting in Economics, 2012 


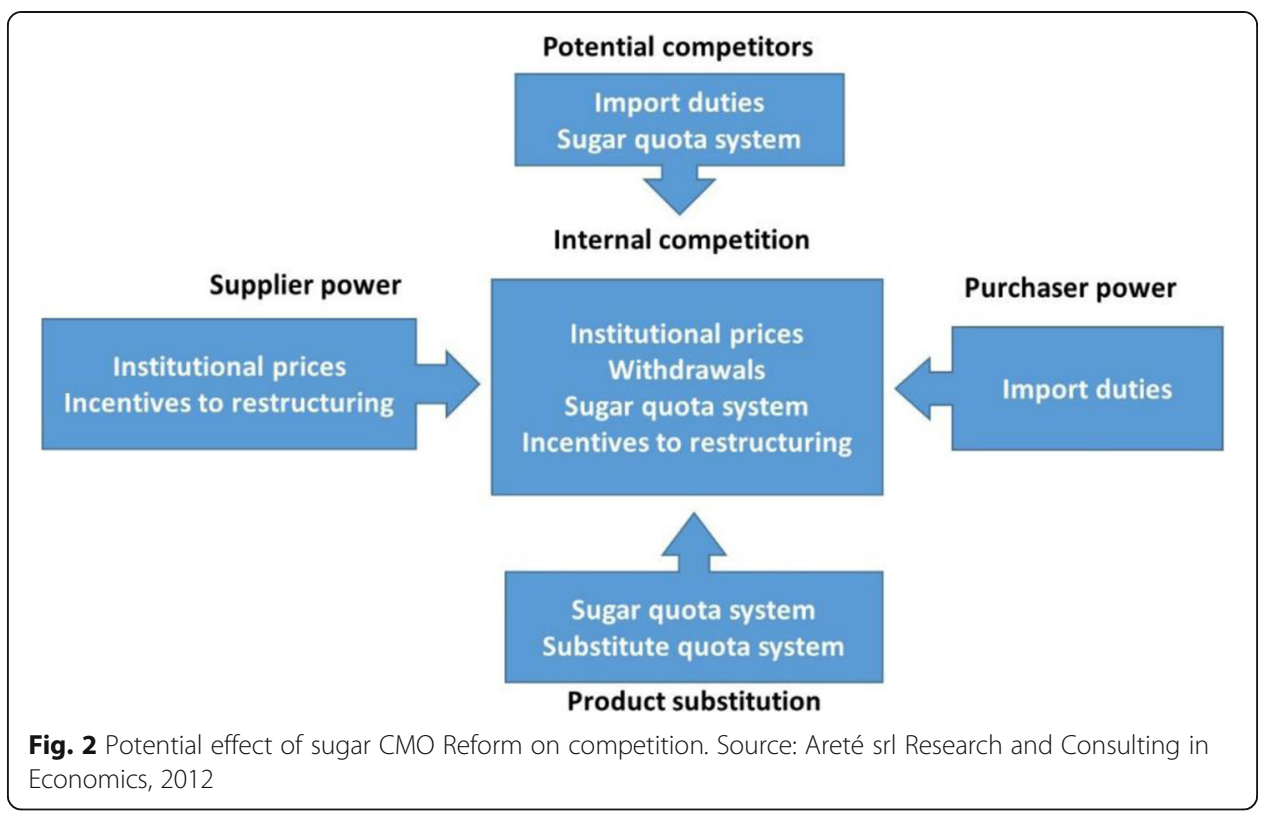

In line with what has been stated above, increased concentration might influence sugar companies' behaviour according to the SCP paradigm, potentially reducing internal competition. Individual measures may have different effects on the five forces. As mentioned above, the reduction of institutional prices is likely to increase cost competition (internal competition) among domestic sugar producers. The new quota system, together with continuing import duties regime, still protect domestic industry from competition (especially from generic Third Countries exporting to the EU market). In this framework, only exporting Countries under tariff exemption may increase the competition on the domestic market (depending on the import volume and on price differential between EU and world market), contributing to increase the market power of sugar purchasers (e.g. confectionery industry, retailers).

Looking at this phenomenon from another point of view, it can be expected that the incentives to the reduction or termination of sugar production provided by the EU restructuring fund, in combination with the EU enlargement process (which, as a result, created more favourable conditions for the implementation of merger and acquisition strategies by increasing the number of potential firms to be merged/ acquired) promoted an increase in the concentration of the EU sugar sector. The final result on competition is uncertain. On the one side, according to classical SCP paradigm, all the above elements should theoretically lead to a reduced competition within the sugar sector because of the reduced price support, the revised quota system, the incentives to industrial restructuring, and the improved access to the EU market, considered separately and according to their combined effect on concentration. On the other side, increased concentration does not necessarily determine a decrease in competition, as sugar producers may react to or anticipate policy effects and implement competitive strategies to reshape the organisation of the sugar supply chain (also in its geographic aspects) in a way to offset, totally or 
in part, potential increases in the degree of competition within the sector, the final effect depending on the balance of the forces on the field.

\section{Empirical assessment of CAP reform effects Vertical price transmission}

The empirical assessment investigated about intensity and speed of VPT and on the existence of asymmetries. The visual inspection revealed that the three-step reduction of sugar intervention price between 2006/07 and 2009/10 (and conclusion of intervention purchases from the 2010/11 campaign onwards), which was implemented by the 2006 reform, did not fully translate in a decrease of ex-work sugar prices in the EU. Indeed, ex-work prices stayed well above the intervention price until the end of the 2009/10 marketing year, and kept a wide margin over the reference price from October 2009 onwards. Evidence also suggests that the reduction of sugar beet minimum prices introduced by the 2006 reform did not fully translate into an equivalent decrease of sugar beet prices.

Table 4 briefly summarises the relevant result of the statistical elaboration, focusing in particular on asymmetries in VPT. As in Table 3 above, the available data allowed for comparison before and after the reform only for a limited number of cases in each group of MS. In the EU-15, VPT asymmetries were discovered in all the tested MS: in particular, there are asymmetries toward price increase and in the relation between ex-work prices toward retail prices. The same holds true for most MS after the reform, except for two cases. In the opposite direction, that is the relation between retail prices and ex-work prices, data are less homogeneous. However, they seem to confirm the same trend before and after the reform. Asymmetries in intensity and speed show a scattered landscape which does not allow to identify clear trends across countries before and after the reform break. In the NMS-12, the available data allowed for a complete investigation of a handful of cases. Poland shows a situation similar to EU-15 while in the other cases no clear trend could be identified.

Table 4 Asymmetries in vertical price transmission

\begin{tabular}{|c|c|c|c|c|c|c|c|c|c|}
\hline & \multirow{3}{*}{$\begin{array}{l}\text { Member } \\
\text { States }\end{array}$} & \multicolumn{4}{|c|}{ Ex-work price to retail price } & \multicolumn{4}{|c|}{ Retail price to ex-work price } \\
\hline & & \multicolumn{2}{|c|}{ Toward price increase } & \multicolumn{2}{|c|}{ Toward price decrease } & \multicolumn{2}{|c|}{ Toward price increase } & \multicolumn{2}{|c|}{ Toward price decrease } \\
\hline & & $\begin{array}{l}\text { Pre- } \\
\text { reform }\end{array}$ & $\begin{array}{l}\text { Post- } \\
\text { reform }\end{array}$ & $\begin{array}{l}\text { Pre- } \\
\text { reform }\end{array}$ & $\begin{array}{l}\text { Post- } \\
\text { reform }\end{array}$ & $\begin{array}{l}\text { Pre- } \\
\text { reform }\end{array}$ & $\begin{array}{l}\text { Post- } \\
\text { reform }\end{array}$ & $\begin{array}{l}\text { Pre- } \\
\text { reform }\end{array}$ & $\begin{array}{l}\text { Post- } \\
\text { reform }\end{array}$ \\
\hline \multirow[t]{6}{*}{ EU-15 } & France & $x$ & $x$ & - & - & $x$ & - & - & - \\
\hline & Germany & $x$ & $x$ & - & - & - & - & - & - \\
\hline & Greece & $x$ & $x$ & - & - & $x$ & $x$ & - & - \\
\hline & Netherlands & $x$ & $x$ & - & - & - & - & - & - \\
\hline & Spain & $x$ & - & - & - & $x$ & $x$ & - & - \\
\hline & $\begin{array}{l}\text { United } \\
\text { King. }\end{array}$ & $x$ & - & - & - & - & - & - & - \\
\hline \multirow{3}{*}{$\begin{array}{l}\text { NMS- } \\
12\end{array}$} & Czech Rep. & - & - & - & - & - & - & - & $x$ \\
\hline & Poland & $x$ & $x$ & - & - & $x$ & - & - & - \\
\hline & Romania & - & $x$ & - & - & - & $x$ & - & - \\
\hline
\end{tabular}

Source: adapted from Areté srl Research and Consulting in Economics, 2012 


\section{Concentration and competition}

In the pre-reform period, we witnessed an already concentrated structure, which the changes introduced by the reform made even more concentrated at both EU and MS levels. Concentration in the EU sugar sector increased remarkably in the post-reform period due to important transnational developments at the EU level (see Table 1 above). ${ }^{6}$ A number of Member States experienced significant and even substantial increases in the HHI since the first campaign under the reformed regime (2006/07). The most remarkable increases occurred in the Netherlands and Hungary, where a single producer was in operation from, respectively, 2007/08 to 2008/09 campaigns onwards. Concentration increased significantly after the reform in France, Italy, Spain and Belgium within the EU-15, and in the Czech Republic and Slovakia among the NMS-12.

Competition was studied in relation to a number of variables. ${ }^{7}$ The main trends from the pre-reform to the post-reform period are:

- An acceleration in the decrease of operating sugar producers

- Greater emphasis on the achievement of scale economies: scale economies were achieved mainly by closing less performing plants and expanding the production capacity of the remaining ones

- The potential beneficial influence of additional imports on competition (i.e. entry of new operators on national markets) might have been partially offset by the control exerted by EU sugar producers on a portion of such flows through their overseas subsidiaries and/or long-term supply agreements. In any case, it is important to underline that the price premium over the international market is the key driver behind preferential imports (mostly coming from African, Caribbean and Pacific countries (ACP countries) and Least Developed Countries (LDCs)) and it is generally achieved on the EU market

- No elements suggest an evident relation between concentration levels and the evolution of the degree of competition in the sugar sector

This last issue, i.e. the existence of a relationship between competition and concentration, was empirically investigated through the correlation analysis between the ALI and the HHI. Results are displayed in Table 5. It is valuable to bear in mind that ALI is inversely related to competition (the greater the index, the lower the competition), while the $\mathrm{HHI}$ is directly related to concentration (the greater the value, the greater the concentration). This means that positive and high values of correlation between ALI and HHI sketch a situation in which high concentration corresponds to reduced competition. Such situation occurs in a few countries, namely France, Poland, Romania and Spain. Moreover, different trends appear before and after the reform: correlation increased in France and Spain, whereas it was rather stable in Poland and reversed in the UK.

\section{Discussion}

The main objective of the research was to extensively test the effect of the sugar reform on VPT and on concentration and competition within the EU. The first hindrance to accomplish this task was data limitation. Indeed, data were not homogeneous across countries and, in some instances, the data series were not complete enough to allow for a geographically extensive analysis across all of the EU MS. 


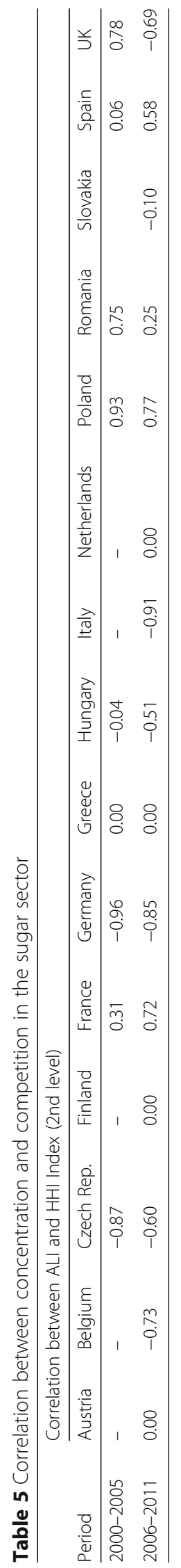


Some of such limitations also affected the analysis of the correlation between concentration and competition. As mentioned in "Testing concentration and competition", the ALI does not allow for comparison in absolute terms, but only trend comparison among countries. In other words, it does not allow to measure the actual degree of competition, as it just appreciates its dynamics over time. Furthermore, the ALI does not allow to understand whether variations in sugar price or in sugar production cost predominantly drive the evolution of competition.

The data limitations notwithstanding, a trend to the prevalence of VPT asymmetries toward price increase seems to prevail both from ex-work to retail price and the other way around. On the one hand, this means that when ex-work price increased, retail price followed. However, it also means that the reduction of ex-work price was not fully transmitted to retail, causing the distance in absolute terms between ex-work and retail prices of sugar in the EU to tendentially increase over time.

On the other hand, asymmetries toward price increase from retail to ex-work price implies that sugar producers were often able to follow (more or less proportionally, and with different extent of delay) price increases coming from the retail sector, while downward variations of retail prices have not resulted in an analogous response by sugar producers. ${ }^{8}$

Data on concentration showed that the reform also determined an increased concentration of the sector. This, however, follows a long-term trend which is, at least in part, endogenous, i.e. not strictly depending on the reform itself, and in part it falls under the dynamics of the long-term history of the sector. An interesting aspect of this trend leads to outline the relation between the role, which should have been played by preferential sugar imports from ACP/LDCs, and the strategies of the EU sugar companies, which have probably tried to counteract the potential effect of preferential imports on internal competition by reshaping the organisation of the sugar supply chain (also in its geographic aspects, as mentioned in "Concentration and competition").

As for the degree of competition, the dynamics of the ALI suggests the presence of a trend toward a higher degree of competition in the sugar sector following the 2006 reform. However, such conclusion should be considered against the abovementioned limitations stemming from the use of the ALI, and also considering further developments in the evolution of concentration and competition in the EU sugar sector occurred during the first months of 2012.

If it is true that the ALI constitutes a synthetic index of the degree of competition which takes into account also the effect of increased sugar imports, and hence of the possible entry of new operators on the EU market, it should be conceded that it cannot adequately represent the many qualitative aspects which may determine actual competition within the EU sugar sector. In this respect, it is also extremely important to underline that the average EU ex-work sugar price remarkably increased over the first months of 2012 in comparison with late 2011 levels. Such price dynamics might have affected the recent evolution of the ALI, especially if sugar production cost has not experienced an analogous evolution over the same period. Hence, these price dynamics also suggest that EU sugar producers might again be exerting remarkable market power, keeping in mind that price dynamics on the EU market mainly derive from the evolution of market fundamentals, which can be influenced by policy decisions taken by the European Commission. 
The relation between concentration and competition finally allows for some consideration about the suitability of the basic of SCP paradigm in capturing the relevant determinant of industrial competition and structure. Theoretical investigation was not among the aims of this study, which nevertheless added some empirical elements to the debate, as we briefly summarised in Table 5 above. Taking into account the limitation of the ALI we used to calculate the correlation, results make sense and are varied. SCP paradigm seems to be confirmed in the same number of MS where it is not. Considering the type of strategies adopted by the sugar companies before and after the reform, we are tempted to claim that the most relevant criticism to the classical SCP paradigm, i.e. the feedback from firms' strategies on the sector structure, has indeed a reason of being true. Beside this, from the study did not emerge any further element, which can support the theoretical debate on this issue, so we leave this cue as a message for further investigations. ${ }^{9}$

\section{Conclusions}

The assessment we carried out provided empirical evidence, which partly confirmed the actual occurrence of the expected effects of the reform on price transmission in the sugar sector.

If market efficiency requires that any change in upstream sector of the supply chain translates into a corresponding change of retail price downstream, the empirical evidence suggests the EU sugar market after the reform is still far from achieving complete efficiency, despite significant steps were made in this direction.

At the same time, the reform contributed to accelerate the on-going process of concentration of the sugar industry, at both the national and the EU level. The possible presence of a trend toward a higher degree of competition (at least up to end 2011) is confirmed within the limits of the competition index adopted in this study. And also within a competitive context in which EU sugar producers might still exert remarkable market power, within the limits allowed by the evolution of market fundamentals and by policy decisions taken by the European Commission.

It can be concluded that the reform has contributed to improve the conditions of the price transmission mechanism, by removing some important constraints and freeing variation of domestic sugar prices, eventually starting a process which might lead to an improved price transmission in the EU sugar sector, if combined with other non-policy developments.

Despite significant progresses were made, from 2011 the expected effects of policy changes on vertical price transmission in the sugar sector have only partially occurred. Changes in the EU sugar regime are probably not deep enough in order to promote full price transmission along the entire sugar supply chain (i.e. down to the final consumption stage) in absence of the contribution of changes in other policies and of favourable non-policy developments.

Actually, the functioning of vertical price transmission in the sugar sector is remarkably affected by the state of competition in the downstream levels of the supply chain (food industry, distribution), over which the EU sugar regime bears no direct influence. The assessment highlighted the evident asymmetry toward price increases with retail prices reacting to increases more often than to decreases in ex-work prices. This implies that operators in the downstream sectors are prone to 
adopting such pricing behaviour: it is unlikely that they will change it in absence of any pressure in this direction.

\section{Endnotes}

${ }^{1}$ Areté Research \& Consulting in Economics (2012), Study on price transmission in the sugar sector. Final report October 2012. The European Commission, DG Agriculture and Rural Development, Brussels (http://ec.europa.eu/agriculture/external-studies/ sugar-price-transmission_en.htm). EU tender reference: European Commission-DG Agriculture and Rural Development. TENDER N AGRI-2011-EVAL-03.

${ }^{2}$ A further policy break was adopted, the WTO creation in 1995, but it only applied to the analysis of horizontal price transmission.

${ }^{3}$ Price transmission at intermediate stages of the supply chain could not be tested quantitatively. Qualitative considerations were derived from evidence concerning the Italian and the British markets.

${ }^{4}$ Three hypotheses were considered for the timing of such break: (a) achievement of a political compromise on the content of the reform (November 2005); (b) publication of the implementing regulation on the Official Journal (March 2006); (c) entry into force of the regulation (July 2006-start of the first EU sugar marketing year under the reformed regime).

${ }^{5}$ Main data sources were Official Journal of the European Union (relevant legislation); EUROSTAT and DG Agriculture (sugar supply balance and other sugar sector data, including ex-work sugar price); EUROSTAT-COMEXT (sugar trade data); LIFFE (London refined sugar price), FCB Commodity Price Index (sugar based commodities and food); national statistical institutes (sugar production data); Bartens Verlag "Sugar Economy Europe" yearbook and F.O. Licht's "International Sugar \& Sweetener Report" (information on sugar structure and strategies)

${ }^{6}$ The termination of the Eurosugar alliance in January 2010 brought to a decrease in concentration at EU level, which remains however remarkable (HHI at EU-27 level was equal to 1.207 points in the 2010/11 campaign). In detail: number of sugar producers at the second level of aggregation (EU level) and at the first level of aggregation (Member State level); number of beet sugar factories in operation (EU level); average production capacity of beet sugar factories (EU level); self-sufficiency ratio and share of imports on internal use for human consumption (EU level); Adjusted Lerner Index ALI (Member State level only).

${ }^{7}$ In detail: number of sugar producers at the second level of aggregation (EU level) and at the first level of aggregation (Member State level); number of beet sugar factories in operation (EU level); average production capacity of beet sugar factories (EU level); self-sufficiency ratio and share of imports on internal use for human consumption (EU level); Adjusted Lerner Index-ALI (Member State level only).

${ }^{8}$ As in note 3 , the influence of market intermediaries on vertical price transmission could not be tested empirically for absence of adequate data. A qualitative assessment suggested that pricing behaviour of market intermediaries in the pre-reform period was basically neutral with respect to vertical price transmission, whereas after the reform increased price volatility induced market intermediaries to vary more frequently their margins according to market conditions and type of customer thus exerting a more significant influence on price transmission along the supply chain in particular market 
conditions. Finally, the pricing behaviour of sugar merchants shows a certain asymmetry toward price increases.

${ }^{9}$ To conclude, let us make reference to Peltzman words once more: "My findings suggest some caveats and perhaps other paths for future research. I found no asymmetry when I examined the response of a single decision maker to its own costs. By contrast, I found above-average asymmetry between factory and consumer prices when there were many small intermediaries between the factory and the retailer. This suggests that an explanation for asymmetry may require a fuller understanding of those vertical market linkages". (Peltzman, 2001, p. 494).

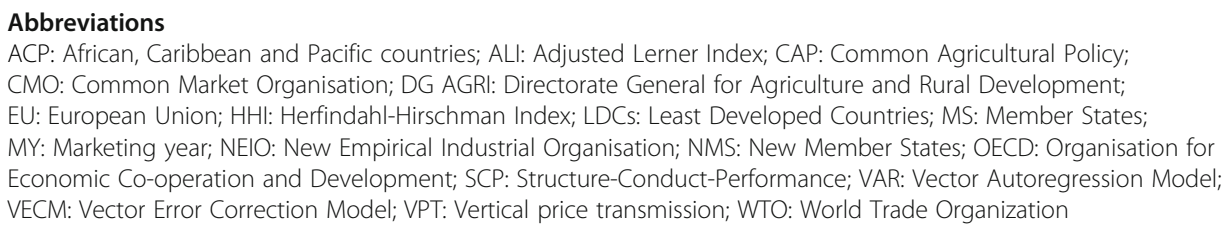

\title{
Acknowledgements
}

This paper has been selected as a best paper of the 52nd SIDEA Conference in Rome-Viterbo (17-19 September 2015). It has been accepted for publication in this journal following the usual revision process. The Authors wish to thank Dr. Enrica Gentile for coordinating and connecting Authors during writing and revision sessions.

\section{Authors' contributions}

The authors are equally responsible for the different sections of the paper. All authors read and approved the final manuscript.

\begin{abstract}
Authors' information
Maurizio ARAGRANDE (PhD) is a Professor of Agricultural Economics at the University of Bologna. Since 2002 co-ordinator, team leader and author of studies for the European Commission and the European Parliament and other international institutions (FAO, OIE). He has experience in policy evaluation and methodology design concerning the agro-food sector also according to innovative approaches (system approach inter-disciplinarity). He is involved in European network focused on the economic evaluation of complex interventions and policies, in the framework of EU COST Action programme. Mauro BRUNI (PHD) is a Co-founder and partner at Areté srl, research and consultancy company specialised on the agriculture and agro-food sector. Since 2002 he has been consultant in a number of studies and projects for the European Commission (DG Agri, DG Sanco, DG Enter, DG Growth, JRC, EFSA), the European Parliament and a number of other institutions at the national and international level, as well as for private companies in the agro-food sector. Expert in the field of agricultural policy, agricultural markets and agro-food economics, with a deep and long term experience on the sugar sector.

Alberico LOI (PhD) is an Agribusiness economist, 13 years of experience as consultant for the European Commission (DG Agriculture, DG SANTE, DG Enterprise/DG Growth, JRC, EFSA) and the European Parliament, as well as for major organisations and companies; experience in the evaluation of EU policies applied to the agro-food sector, with a specific knowledge of the sugar sector and of the related markets and policies, in the EU and third countries. Roberto ESPOSTI (PhD) is an Associate Professor in Economic Policy at the Università Politecnica delle Marche, he teaches courses in Economic Policy, Economics of the Environment and Natural Resources, Panel Da ta Econometrics. $\mathrm{He}$ is also deputy Director of the Department of Economics and Social Sciences and Member of the Board of Directors of Università Politecnica delle Marche.
\end{abstract}

Competing interests

The authors declare that they have no competing interests.

\section{Publisher's Note}

Springer Nature remains neutral with regard to jurisdictional claims in published maps and institutional affiliations.

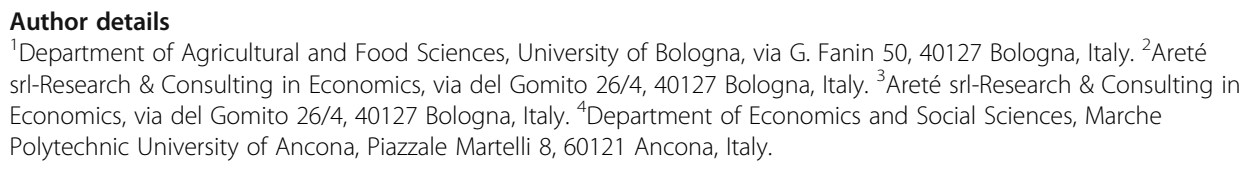


Aragrande M, Canali M (2017) Animal health and price transmission along livestock supply chain. In "Economics of Animal Health" edited by J. Rushton. Scientific and Technical Review, Office Internationale des Epizooties (OIE)/ World Organization of Animal Health, 36 (1), pp. 87-96

Areté srl Research and Consulting in Economics (2012), Study on price transmission in the sugar sector. Final report October 2012, the European Commission, DG agriculture and rural development, Brussels. (https://ec.europa.eu/ agriculture/external-studies/sugar-price-transmission_en. Accessed 13 July 2017)

Azzam A (1999) Asymmetries and rigidities in farm-retail price transmission. Am J Agric Econ 81(3):525-533

Bain JS (1951) Relation of profit rate to industry concentration: American manufacturing, 1936-1940. Q J Econ 65(3): 293-324

Balcombe K, Bailey A, Brooks J (2007) Threshold effects in price transmission: the case of Brazilian wheat, maize and soya prices. Am J Agric Econ 89(2):308-323

Ball L, Mankiw GN (1994) Asymmetric adjustment and economic fluctuation. Econ J 104(423):247-261

Bakucs Z, Falkowski J, Fertő I (2014) Does market structure influence price transmission in the agro-food sector? A meta-analysis perspective. J Agric Econ 65(1):1-25

Bettendorf I, Verboven F (2000) Incomplete transmission of coffee beans prices: evidence from the Netherland. Eur Rev Agric Econ 27(1):1-16

Bolotova Y, Novakocic A (2012) The impact of New York state milk price gauging law on the price transmission and supermarket pricing strategies in the fluid whole milk market. Agribusiness 28(4):377-399

Bonnet C, Réquillart V (2013) Impact of cost shocks on consumer prices in vertically-related markets: the case of the French soft drink market. Am J Agric Econ 95(5):1088-1108

Bresnahan T (1989) Empirical studies of industries with market power. In Handbook of Industrial Organization, vol. II, chapter 17, edited by R. Schmalensee and R.D. Willig. Elsevier Science Pubilisher B.V

Bukeviciute L, Dierx A, Ilzkovitz F (2009) The functioning of food supply chain and its effect on food prices in the European Union, occasional papers n. 47, may 2009, directorate general for economic and Financial Affairs of the European Commission, Brussels (http://ec.europa.eu/economy_finance/publications/pages/publication15234_en. pdf. Accessed 13 July 2017)

Cacchiarelli L, Lass D, Sorrentino A (2016) CAP reform and price transmission in the Italian pasta chain. Agribusiness 32(4):482-497

Cavicchioli D (2010) Detecting market power along the food supply chain: evidence from the fluid milk sector in Italy. Paper prepared for the 116th EAAE seminar "spatial dynamics in the agro-food system: implications for sustainability and consumer welfare" Parma (I) October 27 th-30th, 2010 (https://www.researchgate.net/profile/ Daniele_Cavicchioli/publication/254386681_Detecting_Market_Power_Along_Food_Supply_Chains_Evidence_ From the Fluid_Milk_Sector_in_Italy/links/Odeec53c4d6733fd26000000.pdf. Accessed 13 July 2017)

Chavas JP, Mehta A (2001) Price dynamics in a vertical sector: the case of butter. Am J Agric Econ 86(4):1078-1093

Dejgård JD, Møller AS (2007) Vertical price transmission in the Danish food marketing chain, Fødevareøkonomisk Institut, Københavns Universitet. FOl working paper, no. 2007/8. (http://curis.ku.dk/ws/files/134788710/FOI_WP_ 2007 8.pdf. Accessed 13 July 2017)

Digal LN, Ahmadi-Esfahani FZ (2002) Market power in the retail food industry: a survey of methods. Aust J Agric Resour Econ 46(4):559-584

Engle R, Granger C (1987) Co-integration and error correction: representation, estimation and testing. Econometrica 55 $251-276$

Ferrucci G, Jiménez-Rodriguez R, Onorante L (2010) Food price pass-through in the euro area. The role of asymmetries and non-linearities. European Central Bank. Working paper series no. 1168, April 2010 (https://papers.ssrn.com/sol3/ papers.cfm?abstract_id=1578209. Accessed 13 July 2017)

Frey G, Manera M (2007) Econometric models of asymmetric price transmission. J Econ Surv 21(2):349-415

Goodwin BK, Harper DC (2000) Price transmission, threshold behaviour and asymmetric adjustment in the U.S. pork sector. J Agric Appl Econ 32(3):543-553

Hamulczuk M, Szajner P, (2015) Sugar prices in Poland and their determinants. Problems of Agricultural Economics, 4 345: $59-79$

Kimmel S (2009) Why prices rise faster than they fall. U.S. economic analysis group, antitrust division, U.S. Department of Justice. Discussion paper, EAG 09-4, July 2009. http://citeseerx.ist.psu.edu/viewdoc/download?doi=10.1.1.918. 7612\&rep=rep1\&type=pdf. Accessed 13 July 2017)

Kinnucan HW, Forker OD (1987) Asymmetry in farm-retail price transmission for major dairy products. Am J Agric Econ 69(2):285-292

Listorti G, Esposti R (2012) Horizontal price transmission in agricultural markets: fundamental concepts and open empirical issues. Bio-based and Applied Economics, 1(1), 81-108

McCorriston S, Morgan WC, Rayner AJ (2001) Price transmission: the interaction between firm behaviour and returns to scale. Eur Rev Agric Econ 28(2):143-159

Meyer J, Von Cramon-Taubadel S (2004) Asymmetric price transmission: a survey. J Agric Econ 55(3):581-611

Nolte S, Natanelov V, Buysse J, Van Huylenbroeck G (2012) Price transmission in the German sugar market, contributed paper prepared for presentation at the $56^{\text {th }}$ Australian Agricultural \& Resource Economics Society annual conference, Fremantle, Western Australia, February 7-10, 2012. http://ageconsearch.umn.edu/record/124351/files/ 2012AC\%20Nolte\%20CP.pdf. Accessed 13 July 2017)

OECD (2007) Sugar policy reform in the European Union and in world sugar markets, OECD Committee for Agriculture. OECD publishing, Paris 2007 (http://www.keepeek.com/Digital-Asset-Management/oecd/agriculture-and-food/ sugar-policy-reform-in-the-european-union-and-in-world-sugar-markets_9789264040212-en\#.WSrR50m1vcs. Accessed 13 July 2017)

Peltzman S (2000) Prices raise faster than they fall. J Polit Econ 108(3):466-502 The University of Chicago Press Porter M (1985) Competitive advantage. Creating and sustaining superior performance. Free Press, New York Reagan P, Weitzman M (1982) Asymmetries in price and quantity adjustments by the competitive firm. J Econ Theory 27(2):410-420 
Rezitis AN, Stavropoulos KS (2011) Price transmission and volatility in the Greek broiler sector: a threshold Cointegration analysis. Journal of Agricultural \& Food Industrial Organization 9(1), Article 11. https://www.degruyter.com/view/j/ jafio.2011.9.issue-1/issue-files/jafio.2011.9.issue-1.xml. Accessed 31 Aug 2017

Sheldon I, Sperling R 2003 Estimating the extent of imperfect competition in the food industry: what have we learned? J Agric Econ 54 1: 89-109

Sims C (1980) Macroeconomics and reality. Econometrica 48(1):1-48

Varga T (2007) Vertical price transmission between market operators in Hungarian agricultural product chains. Studies Agricultural Economics 106:41-70

Vavra P, Goodwin B (2005), Analysis of price transmission along the food chain. OECD food, agriculture and fisheries working papers, no. 3, OECD publishing. (http://www.Oecd.Org/Agriculture/Agricultural-policies/40459642.Pdf. Accessed 13 July 2017)

Wang X, Weldegebriel H, Rayner T (2006) Price transmission, market power and return to scale. Land economy working paper series no. 19. SAC, Edinburgh (Nov., 2006), (http://ageconsearch.Umn.Edu/record/46004/files/Work19Habtu. Pdf. Accessed 13 July 17)

Wohlgenant M (1985) Competitive storage, rational expectations, and short-run price determination. Am J Agri Econ 67(4):739-748

Xia T (2009) Asymmetric price transmission, market power, and supply and demand curvature. J Agri Food Ind Organ 7(1), Article 6. https://www.degruyter.com/view/j/jafio.2009.7.1/issue-files/jafio.2009.7.issue-1.xml. Accessed 31 Aug 2017

Submit your manuscript to a SpringerOpen ${ }^{\circ}$ journal and benefit from:

- Convenient online submission

- Rigorous peer review

- Open access: articles freely available online

- High visibility within the field

- Retaining the copyright to your article

Submit your next manuscript at $\boldsymbol{s p r i n g e r o p e n . c o m ~}$ 